\section{Monoecious-flowering, Tetraploid, Virescent Melon C879-J2-4X}

\author{
Perry E. Nugent \\ U.S. Vegetable Laboratory, Agricultural Research Service, U.S. Department \\ of Agriculture, 2875 Savannah Highway, Charleston, SC 29414 \\ Additional index words. muskmelon, cantaloupe, Cucumis melo, mutant line, seedling \\ $\mathrm{m}$ u t a $\mathrm{n} \mathrm{t}$
}

A tetraploid version of the chlorophylldeficient seedling, white-flowered virescent (v) markermelon (Cucumis melo L.) (Hoffman and Nugent, 1973; Nugent, 1981), recovered from a 1987 C879-J2 observational plot, led to the development and release of the $4 \mathrm{x}$ germplasm C879-J2-4X in 1991 by the Agricultural Research Service, U.S. Dept. of Agriculture. This $4 \mathrm{x}$ virescent marker line can be used for examining pollination, pollen flow dynamics, genetic analysis, and hybrid seed production practices. C879-J2-4X is a high-quality, multiple-resistant, virescent melon breeding line with twice the normal number of chromosomes $(\mathrm{n}=\mathrm{x}=24)$ as its diploid $(\mathrm{n}=\mathrm{x}=24$ chromosomes) parent (Nugent and Ray, 1992). C879-J2-4X provides public and private muskmelon breeders with a source of improved monoecious, virescent germplasm for developing $4 \mathrm{x}$ inbred lines and triploid $(3 \mathrm{x})$ hybrid cultivars. Seedless $(3 x)$ melons have been produced from crosses between severa $14 \mathrm{x}$ and 2x lines in 1990-91 by Adelberg (1993).

\section{Origin}

The recessive virescent character described was discovered in 1967 and the germplasm further refined through a complex series of crosses and selections (Hoffman and Nugent, 1973; Nugent, 1987) involving the cultivars Mainstream, Rocky Ford, Netted Gem, PMR 450, Hearts of Gold, Planters Jumbo, Georgia 47, and PMR 6. Plant introductions 124111, 124112,164323 , and 193495 are also in the background of the C879 marker line. A detailed description and pedigree of $\mathrm{C} 879$ has been published (Nugent, 1987). C879-J2-4xis a spontaneous tetraploid mutant version of C879. It was found in a 1987 field planting of the $2 \mathrm{x}$ powdery-mildew-resistant and downymildew-tolerant C879-J2.

\section{Description}

The $4 \mathrm{x}$ version of $\mathrm{C} 879$ is similar to its $2 \mathrm{x}$ parent, but there are clearly discernible differences that make it possible to identify $2 \mathrm{x}$ and

Received for publication 25 Feb. 1993. Accepted for publication 6 Aug. 1993. The cost of publishing this paper was defrayed in part by the payment of page charges. Under postal regulations, this paper therefore must be hereby marked advertisement solely to indicate this fact.

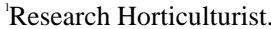

4x plants without measurements. Tetraploid plants, growing with their diploid counterparts under similar conditions, have slightly more rounded cotyledons, shorter internodes, thicker leaves, and more hairs. Their creamcolored flowers (Fig. 1), which are $\approx 33 \%$ larger than those of $2 x$ plants, fade quickly to white in bright sunlight and have yellow centers and orange stigmas. Their stomates are rounder and one-fourth to one-third larger than those of $2 \mathrm{x}$ plants, and $4 \mathrm{x}$ pollen grains are square rather than triangular. Seeds from $4 \mathrm{x}$ plants are slightly shorter and wider than $2 x$ seeds. The smaller fruit ( 0.8 to $1.0 \mathrm{~kg}$ vs. 1.2 to $1.6 \mathrm{~kg})$ of $4 \mathrm{x}$ types have thicker, firmer, higher-quality flesh and fewer (one-fourth to one-half as many) seeds than the $2 x$ parent (Nugent and Ray, 1992).All C879 fruit have a unique yellow flesh, some with occasional orange streaks, which may be associated with the virescent gene. The stem and blossom scars of $4 \mathrm{x}$ types are at least three times larger than their 2x counterparts (Fig. 2). The C879-J2-4X line segregates for monoecious and andromonoecious flowering habit. C879-J2-4X, like its $2 \mathrm{x}$ parent, is highly resistant to powdery mildew [Sphaerotheca fuliginea (Schlecht ex. Fr.) Poll.] and moderately resistant (reaction type 2) to downy mildew [Psuedoperonospora cubensis (Berk. \& Curt.) Rostow] under natural epiphytotics at Charleston, S.C. In most Charleston growing seasons, C879-J2-4X produces two to four high-qualitynetted fruit per plant without the need of pesticides.

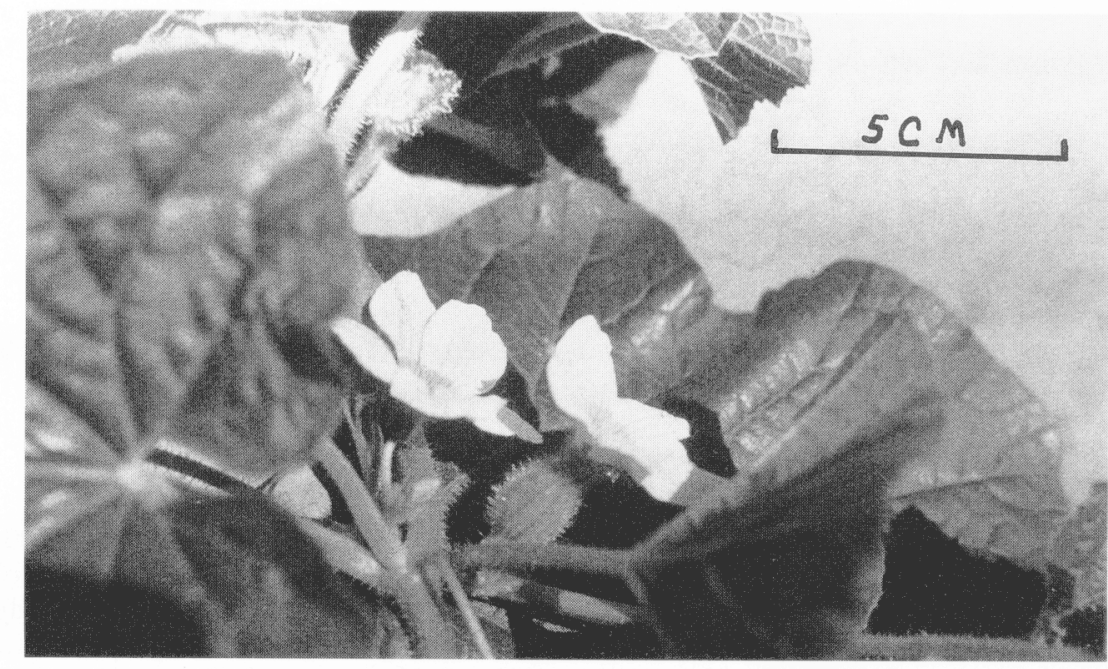

Fig. 1. Foliage and flowers (average $3.8 \mathrm{~cm}$ in diameter) of C879-J2-4X melon.

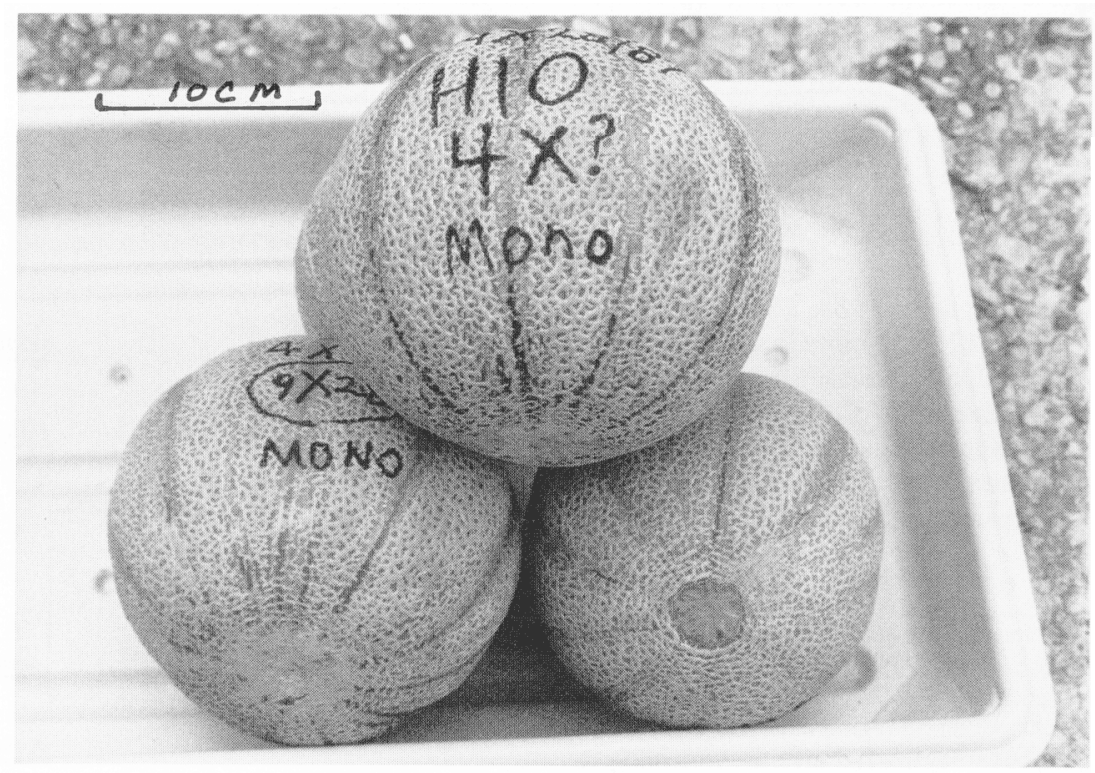

Fig. 2. Fruit of C879-J2-4X melon; fruit weight and diameter were $995 \mathrm{~g}$ and $12.6 \mathrm{~cm}$, respectively. 
uses

The 2x (C879-J2) virescent mutant (Hoffman and Nugent, 1973; Nugent, 1987) has been used in gene-flow and pollination studies (Handel, 1982; Nugent artd Hoffman, 198 1). It has also been used in hybrid seed production experiments and species-crossing studies (Nugent, 1980, 1984; Nugent and Bhella, 1988). C879-J2-4X has similar applicability and can be used to compare growth characteristics at various ploidy levels and to develop new tetraploid lines and triploid seedless melons (Adelberg, 1993).

\section{Culture}

Because of weak initial growth, direct seeding in field plots is not recommended. When compared to $2 \mathrm{x}$ lines not possessing $\mathrm{v}$, growth is delayed by 14 to 21 days while chlorophyll develops. To ensure survival of virescent seed- lings, one can sow seed in potting-mix-filled [e.g., Metro-Mix (Grace Sierra, Milpitas, Calif.)] cellpacks or peat-pellets and give seed careful attention for a few days. Healthy plants (two- to four-leaf stage) cart be field-transplanted and grown using standard melon cultural practices.

\section{Availability}

Samples of this accession are available from P.E.N. on a pro-rata basis to breeders and other scientists upon request. Seed recipients are asked to give appropriate recognition of the germplasm source if it is used in developing a new germplasm, parental line, or cultivar.

\section{Literature Cited}

Adelberg, J. 1993. Tetraploid melon from tissue culture and their triploid hybrids. PhD diss., Clemson Univ., Clemson, S.C.
Handel, S.N. 1982. Dynamics of gene flow in an experimental population of Cucumis melo (Cucurbitaceae). Amer. J. Bet. 69(10):15381546.

Hoffman, J.C. and P.E. Nugent. 1973. Inheritance of a virescent mutant in muskmelon. J. Hered. 64:311-316.

Nugent, P.E. 1980. The genetic relationship of virescent, yellow-green, glabrous, and halo mutants in muskmelon. HortScience 15:804-805.

Nugent, P.E. 1984. The virescent marker as a breeding tool in muskmelon. HortScience 19:211.

Nugent, P.E. 1987. C879-J1 and C879-J2 virescent mutant muskmelon breeding lines. HortScience 22:333-335.

Nugent, P.E. and H.S. Bhella. 1988. A new chlorotic mutant of muskmelon.HortScience23:379381 .

Nugent, P.E. and J.C. Hoffman. 1981. Natural cross pollination in four andromonoecious seedling marker lines of muskmelon. HortScience 16:7374 .

Nugent, P.E. and D.T. Ray. 1992. Spontaneous tetraploid melons. HortScience 27:47-50. 